\title{
Estimating the selectivity of unpaired trawl data: a case study with a pelagic gear
}

\author{
Manu Sistiaga ${ }^{1}$, Bent Herrmann ${ }^{2}$, Eduardo Grimaldo ${ }^{1}$, Finbarr G. O’Neill ${ }^{3}$ \\ ${ }^{1}$ SINTEF Fisheries and Aquaculture (SFA), Brattørkaia 17C, 7010 Trondheim, Norway. E-mail: Manu.Sistiaga@ sintef.no \\ ${ }^{2}$ SINTEF Fisheries and Aquaculture, Fishing Gear Technology, Willemoesvej 2, 9850 Hirtshals, Denmark. \\ ${ }^{3}$ Marine Scotland, 375 Victoria Road, AB9 11DB Aberdeen, United Kingdom.
}

M.S. and B.H. contributed equally to the manuscript

\begin{abstract}
Summary: Most selectivity experiments employ either the covered codend or paired gear methods. It is not always possible, however, to use these methods. Owing to operational, biological and/or environmental considerations, there may be no obvious way or it may be inappropriate to pair the test and control data. Hence, it will not be possible to estimate the selectivity of the gear and its uncertainty using standard statistical methods. This study presents a methodology for analysing the selectivity of fishing gears from unpaired test and control data. The uncertainty in the control and test population structures is accounted for by using a double bootstrapping procedure that takes into account both between-haul and within-haul variation. This bootstrapping approach is used to assess the selectivity of two different devices, a $139.5 \mathrm{~mm}$ T90 codend and a $135.9 \mathrm{~mm}$ codend with $140.9 \mathrm{~mm}$ lateral exit windows, in the Barents Sea pelagic cod trawl fishery. The purpose of the experiment was to test and compare the performance of the two devices in pelagic trawl fisheries, where high densities of fish can be encountered. Significant differences were detected between the T90 codend and the codend with the exit windows but only for sizes of cod between 55 and $76 \mathrm{~cm}$.
\end{abstract}

Keywords: trawl selectivity; pelagic fisheries; unpaired data; cod

\section{Estimando la selectividad en redes de arrastre con lances no pareados: un caso de estudio con una red pelágica}

Resumen: La mayoría de los experimentos de selectividad emplean el método de copo cubierto o el de lances pareados. Sin embargo, la utilización de estos métodos no es siempre posible. En ocasiones, no se puede encontrar una manera lógica de emparejar los datos provenientes de lances de prueba y lances control, o esta puede ser inapropiada debido a consideraciones de tipo operacional, biológico o medioambientales. Por lo tanto, no sería posible estimar la selectividad de la red y la incertidumbre de los resultados obtenidos utilizando métodos estadísticos estandarizados. Este estudio presenta una metodología que facilita el análisis de la selectividad en artes de pesca en los que los datos provienen de lances no pareados. La incertidumbre en las estructuras poblacionales capturadas en los lances prueba y control se tiene en cuenta utilizando un método de doble "bootstrapping" que considera la variabilidad en cada lance y entre lances. Utilizamos este método de "bootstrapping" para estimar la selectividad de dos dispositivos diferentes en la pesca pelágica de bacalao del mar de Barents: un copo T90 con mallas de $139,5 \mathrm{~mm}$ y un copo con mallas romboidales de 135,9 mm con ventanas laterales de 140,9 mm. El propósito del experimento fue comparar el comportamiento de ambos dispositivos en la pesca de arrastre pelágico de bacalao, donde se pueden encontrar altas densidades de pescado. Se detectaron diferencias significativas entre el copo T90 y el copo con las ventanas pero solo para tallas de bacalao comprendidas entre 55 y $76 \mathrm{~cm}$.

Palabras clave: selectividad en arrastre; pesquerías pelágicas; lances no pareados; bacalao.

Citation/Como citar este artículo: Sistiaga M., Herrmann B., Grimaldo E., O’Neill F.G. 2016. Estimating the selectivity of unpaired trawl data: a case study with a pelagic gear. Sci. Mar. 80(3): 321-327. doi: http://dx.doi.org/10.3989/ scimar.04409.26B

Editor: P. Martín.

Received: January 29, 2016. Accepted: June 13, 2016. Published: September 27, 2016.

Copyright: (C) 2016 CSIC. This is an open-access article distributed under the terms of the Creative Commons Attribution (CC-by) Spain 3.0 License.

\section{INTRODUCTION}

Trawls are one of the most widely used fishing gears around the world. They have been adapted to many fisheries, and are capable of being towed on many types of seabed and in the most difficult of weather conditions. As a result, they and more specifically their selectivity are among the most commonly 
investigated fields within fisheries technology. A variety of experimental methodologies have been developed for carrying out selectivity experiments, the main ones being the covered codend and paired gear methods (Wileman et al. 1996). In the covered codend method, fish escaping from the gear are retained in one or more small mesh covers and hence an accurate estimate of the fish that entered the gear can be made. The twin trawl, trouser trawl, parallel haul and alternate haul methods are classified by Wileman et al. (1996) as paired gear methods. In these methods an estimate of the population fished is obtained from a small mesh control gear that is either towed simultaneously on one side of the twin/trouser trawl or from a different vessel (parallel), or towed consecutively from the same vessel which alternates test and control gears. A range of statistical methods have been developed to analyse the data collected during these experiments and to estimate the selective properties of the gears tested (Millar and Fryer 1999). Carrying out these studies at sea is challenging because of operational, environmental and biological factors which are difficult, if not impossible, to control. Consequently, repeat tows generally have large amounts of between-haul variation, which must be accounted for to avoid making incorrect inferences about the selection of the gear (Fryer 1991).

For scientific or operational reasons, it may not always be possible to use the covered codend or any of the above paired gear methods to estimate selectivity. There are, for instance, fisheries where the presence of small mesh covers may influence the fishing performance of the gear (by modifying hydrodynamic conditions or by altering fish behaviour); it may be difficult to deal with two codends on deck simultaneously (twin/ trouser trawl); financial or economic considerations may preclude the use of two vessels (parallel haul); and difficulties and/or time constraints associated with repeated converting of a trawl from test to control may preclude the use of alternate hauls.

Under these circumstances, the most practicable and pragmatic way forward may be to first carry out a number of test hauls and then to carry out a number of control hauls. However, this leads to problems in analysing the subsequent data, as there is no obvious way of pairing the individual test and control hauls. Accordingly, alternative statistical methods must be explored. Here, to address this problem, we combine the test and the control hauls to produce two pooled data sets, from which we estimate the selectivity of the test gear. We then estimate the variance of the corresponding selection parameters by applying a double bootstrapping approach to account for both within-haul and between-haul variation.

We illustrate this approach by applying it to data from selectivity trials in the Barents Sea cod (Gadus morhua) fishery using pelagic trawls with T90 codends or exit windows (EWs). Pelagic trawling is one of the most efficient fishing methods to catch cod at certain times of the year because the species concentrates itself in dense schools in the water column. Although the fishery was banned in the late 1970s, owing to the high percentage of juveniles caught, in recent years a number of vessels have received special permits to exploit it again. At present, these vessels have to use three different types of grids combined with a $130 \mathrm{~mm}$ codend (Herrmann et al. 2013a). There are, however, concerns that, at high entry densities, fish accumulate in front of and behind these grids, blocking the passage to the codend, and hence a desire to test the selectivity of T90 codends and EWs which have proved effective in demersal cod trawls (Grimaldo et al. 2007).

The dimensions of the gears, their catch sizes (which are often $>30 \mathrm{t}$ ) and space limitations on deck precluded the use of the covered codend or twin/trouser trawl methods, and the fact that the trials were carried out under commercial conditions prevented the use of the alternate haul method. From an operational point of view, the practicable way forward was to carry out a number of consecutive tows with the test codend followed by a number of consecutive tows with the small mesh control codend. As set out above, this leads to a situation in which there is no obvious way of pairing the individual test and control hauls. Thus, it precludes the use of the traditional paired gear statistical methodologies and necessitates the development of alternative approaches of the type we introduce here.

\section{MATERIALS AND METHODS}

\section{Sea trials}

Trials were carried out onboard the commercial vessel M/Tr Ramoen (66.7 m LOA, $5170 \mathrm{HP}$ ) from the 19 to 30 October 2011 in the Hopendjupet basin (between $77^{\circ} 05^{\prime}-77^{\circ} 15^{\prime} \mathrm{N}$ and $28^{\circ} 17^{\prime}-30^{\circ} 45^{\prime} \mathrm{W}$ ).

Two different selection devices were tested during this cruise: a diamond mesh codend with EWs; and a T90 codend. To calculate the mesh size of both codends and the EWs, two rows of 20 measurements were made from each using an omega gauge that applied a stretching force of 125 Newtons (Council Regulation (EC) No 517/2008).

The codend with the EWs was made from 135.9 $\mathrm{mm}$ (measured), 8-mm single "Euroline premium" (Polar gold) PE diamond mesh netting. It was of a four-panel design, 120 meshes long and had 72 meshes in circumference. The side panels of the codend were fitted with an EW panel each (Fig. 1A). The EWs were 100 meshes long and 8 meshes high and constructed from 8-mm PA single twine. The meshes in the windows had an average mesh size of $140.85 \mathrm{~mm}$ and were installed as diamond meshes that held a constant opening angle of $90^{\circ}$. The meshes are therefore considered to be square-shaped during fishing.

The T90 codend also followed a four-panel design and had three different sections. The foremost section was made from $8 \mathrm{~mm}$ single "Euroline premium" (Polar gold) PE diamond mesh netting and the meshes in the T0 direction. It was 40 meshes long and had 80 meshes in circumference. The middle section of the codend was constructed with the same netting material as the foremost section but was turned 90 degrees and was 80 meshes long and had 40 meshes in circumference. The third section, at the codline, was identical to the foremost 

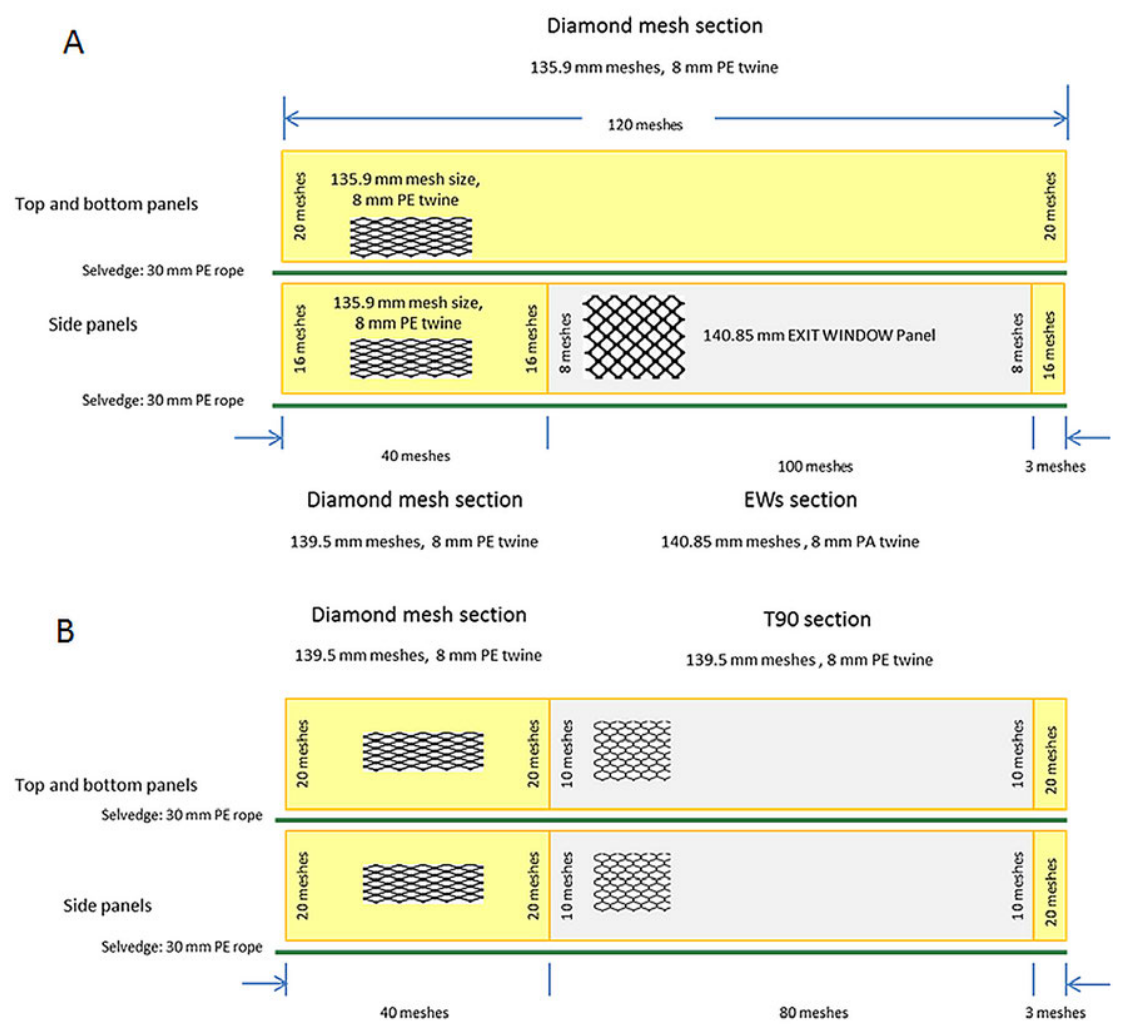

Fig. 1. - Construction details for the codend with the EWs (A) and the T90 codend (B) tested during the experiments.

except that it was 3 meshes long. The average mesh size for this codend was measured to be $139.5 \mathrm{~mm}$.

Roundstraps are known to affect selectivity of codends (Herrmann et al. 2006). Because the codends were used in commercial activity, both codends had $24 \mathrm{~mm}$ diameter Danline round straps of ca. $5.5 \mathrm{~m}$ every $1.20 \mathrm{~m}$.

The trawl used during the experiments was an Egersund 720 HexMesh single belly pelagic trawl. It was rigged with a pair of "Scorpion injector" bottom trawl doors ( $9.5 \mathrm{~m}^{2}$ and $4400 \mathrm{~kg}$ each), $2 \mathrm{~m}$ of $22 \mathrm{~mm}$ chains between the doors and each of the sweeps (top and bottom), $80 \mathrm{~m}$ sweeps, $1200-\mathrm{kg}$ chains as front weight at the end of each bottom sweep, $10 \mathrm{~m}$ of $22-\mathrm{mm}$ chains joining the end of the sweep and the lower wing of the trawl, and a 10-m wire between the top sweep and the top wing. The control hauls used 55-mm inner-net blinders in the codends to estimate the population fished.

The target species for this fishery is cod above a minimum legal size of $44 \mathrm{~cm}$ (Norwegian Fisheries Directorate (J-7-2016) 2016). The trawling operation was carried out as similar as possible to ordinary commercial operations. Therefore, to carry out the trials it was necessary to first collect a number of hauls with the control gear followed by a number of hauls with the test gear. For each haul, random subsamples of the catch were taken and the cod in the sample was measured to the nearest centimetre below. The rest of the cod in each haul was counted.

\section{Data analyses}

As set out above, owing to the experimental procedure followed, there is no obvious way of pairing the data from the individual test and control hauls. Hence, for each gear, to estimate the mean selectivity parameters, the raised length frequency data of the corresponding test hauls were combined and compared with the combined data from the control hauls by minimizing:

$$
\begin{aligned}
& -\sum_{l}\left\{\sum_{i=1}^{a}\left\{\frac{n t_{l i}}{q t_{l i}}\right\} \ln \left(\frac{s p_{a v} r\left(l, \mathbf{v}_{a v}\right)}{s p_{a v} r\left(l, \mathbf{v}_{a v}\right)+1-s p_{a v}}\right)+\right. \\
& \left.+\sum_{i=1}^{b}\left\{\frac{n c_{l i}}{q c_{l i}}\right\} \ln \left(1.0-\frac{s p_{a v} r\left(l, \mathbf{v}_{a v}\right)}{s p_{a v} r\left(l, \mathbf{v}_{a v}\right)+1-s p_{a v}}\right)\right\}
\end{aligned}
$$

where $\tilde{\mathbf{v}}_{\boldsymbol{a}}$ represents the parameters describing the size selection curve defined by $r\left(l, \tilde{\mathbf{v}}_{a v}\right) ; n t_{l i}$ and $q t_{l i}$, and $n c_{l i}$ and $q c_{l i}$ are the number of fish measured in each length class and the fraction of fish measured for each length class for the test and the control hauls, respectively; $a$ and $b$ are the number of test and control hauls; and $s p_{a v}$ is the average split, which quantifies the average relative fishing power between the test gear and the control gear based on the raised and pooled catch data over hauls (Wileman et al. 1996). The outer summation in (1) is over length classes $l$. Equation (1) is identical to the SELECT model (Millar 1992) for raised data pooled over hauls, except for the summations, which are over the hauls conducted respectively with the test and control gears. Thus, in line with Millar et al. (2004), we base the estimation of the average size selection over hauls on the raised catch data. Four different parametric size selection curves were considered for each test gear: the Logit, the Probit, the Gompertz and the Richards 
Table 1. - Haul summary data.

\begin{tabular}{|c|c|c|c|c|c|c|c|c|}
\hline Date & Haul Nr. & Device & $n$ fish measured & $n$ fish counted & Sampling factor & Tow time (min) & Total catch $(\mathrm{kg})$ & Mean catch rate $\left(\mathrm{kg} \mathrm{h}^{-1}\right)$ \\
\hline 24.10 .11 & 12 & Control & 720 & 10877 & 0.066 & 100 & 25296.76 & 15178.06 \\
\hline 24.10 .11 & 13 & Control & 900 & 5524 & 0.163 & 225 & 12939.61 & 3450.56 \\
\hline 24.10 .11 & 14 & Control & 779 & 3883 & 0.201 & 205 & 8654.35 & 2532.98 \\
\hline 25.10 .11 & 15 & Control & 833 & 5740 & 0.145 & 220 & 15157.14 & 4133.77 \\
\hline 25.10 .11 & 16 & Control & 637 & 5136 & 0.124 & 70 & 13035.58 & 11173.35 \\
\hline 25.10 .11 & 17 & EW & 1303 & 13241 & 0.098 & 130 & 35004.91 & 16156.11 \\
\hline 25.10 .11 & 18 & EW & 603 & 3745 & 0.161 & 100 & 9321.34 & 5592.80 \\
\hline 25.10 .11 & 19 & EW & 605 & 6152 & 0.098 & 125 & 15584.95 & 7480.78 \\
\hline 25.10 .11 & 20 & EW & 1035 & 7687 & 0.135 & 10 & 20834.80 & 125008.78 \\
\hline 26.10 .11 & 21 & EW & 1048 & 5666 & 0.185 & 60 & 14920.67 & 14920.67 \\
\hline 26.10 .11 & 22 & Control & 1061 & 9219 & 0.115 & 40 & 20060.40 & 30090.60 \\
\hline 26.10 .11 & 23 & Control & 1194 & 7003 & 0.170 & 120 & 15749.46 & 7874.73 \\
\hline 26.10 .11 & 24 & Control & 972 & 4485 & 0.217 & 100 & 9627.35 & 5776.41 \\
\hline 26.10 .11 & 25 & Control & 905 & 6363 & 0.142 & 145 & 13317.59 & 5510.73 \\
\hline 26.10 .11 & 26 & Control & 874 & 4419 & 0.198 & 165 & 9929.07 & 3610.57 \\
\hline 27.10 .11 & 27 & T90 & 744 & 3400 & 0.219 & 140 & 8820.78 & 3780.34 \\
\hline 27.10 .11 & 28 & T90 & 667 & 4296 & 0.155 & 130 & 9996.42 & 4613.73 \\
\hline 27.10 .11 & 29 & T90 & 903 & 4912 & 0.184 & 60 & 10519.62 & 10519.62 \\
\hline 27.10 .11 & 30 & T90 & 657 & 6018 & 0.109 & 60 & 13602.72 & 13602.72 \\
\hline 27.10 .11 & 31 & Control & 814 & 4340 & 0.188 & 125 & 8676.11 & 4164.54 \\
\hline 28.10 .11 & 32 & Control & 1009 & 6620 & 0.152 & 175 & 12492.78 & 4283.24 \\
\hline 29.10 .11 & 33 & Control & 757 & 2002 & 0.378 & 165 & 4191.46 & 1524.17 \\
\hline
\end{tabular}

curve. The first three models are fully described by the selection parameters L50 (length of fish with 50\% probability of being retained after entering) and SR (difference in length between fish with respectively $75 \%$ and $25 \%$ probability of being retained after entering). The Richard model also requires one additional parameter, $(1 / \delta)$, which is used to model potential asymmetry in the size selection curve. The formulae for the four selection models, together with additional information, can be found in Wileman et al. (1996).

To test the goodness of fit of the data to these curves, the residuals were plotted and the model deviance, $D$, was calculated as follows:

$$
D=2 \operatorname{sign}\left(y_{l}-y m_{l}\right) \sum_{l}\left\{n t_{l} \ln \left(\frac{y_{l}}{y m_{l}}\right)+n c_{l} \ln \left(\frac{1-y_{l}}{1-y m_{l}}\right)\right\}
$$

where

$$
\begin{aligned}
& y_{l}=\frac{n t_{l}}{n t_{l}+n c_{l}} \\
& y m_{l}=\frac{q t_{l} \psi_{l}}{q t_{l} \psi_{l}+q c_{l}\left(1-\psi_{l}\right)} \\
& \psi_{l}=\frac{s p_{a v} r\left(l, \mathbf{v}_{a v}\right)}{s p_{a v} r\left(l, \mathbf{v}_{a v}\right)+1-s p_{a v}} \\
& n t_{l}=\sum_{i=1}^{a} n t_{l i}, n c_{l}=\sum_{i=1}^{b} n c_{l i}, \\
& q t_{l}=\frac{n t_{l}}{\sum_{i=1}^{a}\left\{\frac{n t_{l i}}{q t_{l i}}\right\}}, q c_{l}=\frac{n c_{l}}{\sum_{i=1}^{b}\left\{\frac{n c_{l i}}{q c_{l i}}\right\}},
\end{aligned}
$$

Akaike's Information Criterion (AIC) was used to distinguish between acceptable models and that with the lowest value was chosen (Akaike 1974). If there was overdispersion (deviance/DOF $>1.0$ ), the quasi-AIC (QAIC) was used instead of AIC (Richard 2008). Among the four models considered, that with the lowest estimate for overdispersion was selected and this value was used to calculate the QAIC for the individual models.

The variances and the confidence limits for the parameters of the chosen model were estimated by a double bootstrapping methodology. The procedure followed accounts for between-haul variation by selecting $a$ hauls with replacement from the test hauls and $b$ hauls with replacement from the control hauls during each bootstrap loop. Within-haul variability is accounted for by randomly selecting fish with replacement from each of the selected hauls, where the number selected from each haul is the same as the number that were sampled in that haul. These data are then raised and combined as above and the selectivity parameters are again estimated. By conducting the raising of the data after the re-sampling, the additional uncertainty in estimation caused by subsampling is automatically accounted for (Eigaard et al. 2012). We perform 10000 bootstrap repetitions and hence calculate the Efron $95 \%$ confidence limits for the selection parameters. This bootstrapping approach differs from that of Millar (1993) insofar as he was dealing with covered gear data and, for a given haul, accounted for within-haul variation by randomly selecting with replacement the number caught at each size class according to the proportion retained in the gear during that haul.

\section{RESULTS}

A total of 9 test hauls and 13 control hauls were carried out with the two tested devices. Catch rates were high, with rates $>3000 \mathrm{~kg} \mathrm{~h}^{-1}$ in 21 out of the 22 hauls, up to a maximum of $125009 \mathrm{~kg} \mathrm{~h}^{-1}$. As a result, all the hauls needed to be subsampled and sampling factors ranged from 0.066 to 0.378 . An overview of haul information is given in Table 1.

Of the 9 test hauls, 5 were carried out with the EW codend and 4 with the T90 codend. Table 1 presents the hauls in chronological order and highlights that there is no obvious way of pairing the test and control hauls. Hence, the relevant data were pooled and 
Table 2. - QAIC values obtained with the four tested models for each of the tested selectivity systems.

\begin{tabular}{lcc}
\hline \multicolumn{1}{c}{ QAIC } & Exit Windows & T90 \\
\hline Logit & 73794.33 & 41388.88 \\
Probit & $\mathbf{7 3 7 8 3 . 8 2}$ & 41389.19 \\
Compertz & 73796.56 & 41463.81 \\
Richard & 73786.98 & $\mathbf{4 1 3 1 5 . 5 8}$ \\
\hline
\end{tabular}

Table 3. - Mean and Efron 95\% confidence interval values (based on 10000 bootstrap repetitions) obtained for the selectivity and fit statistical parameters estimated for the two selectivity systems tested in the study.

\begin{tabular}{lcc}
\hline & Exit Windows & T90 \\
\hline L50 & $59.54(53.97-71.76)$ & $51.55(46.78-54.59)$ \\
SR & $15.07(10.21-22.69)$ & $6.56(4.34-9.29)$ \\
$1 / \delta$ & $*$ & $0.022(0.016-0.717)$ \\
SP & $0.459(0.303-0.678)$ & $0.218(0.177-0.272)$ \\
p-value & $<0.001$ & $<0.001$ \\
Deviance & 136.00 & 157.63 \\
d.f. & 71 & 69 \\
\hline
\end{tabular}
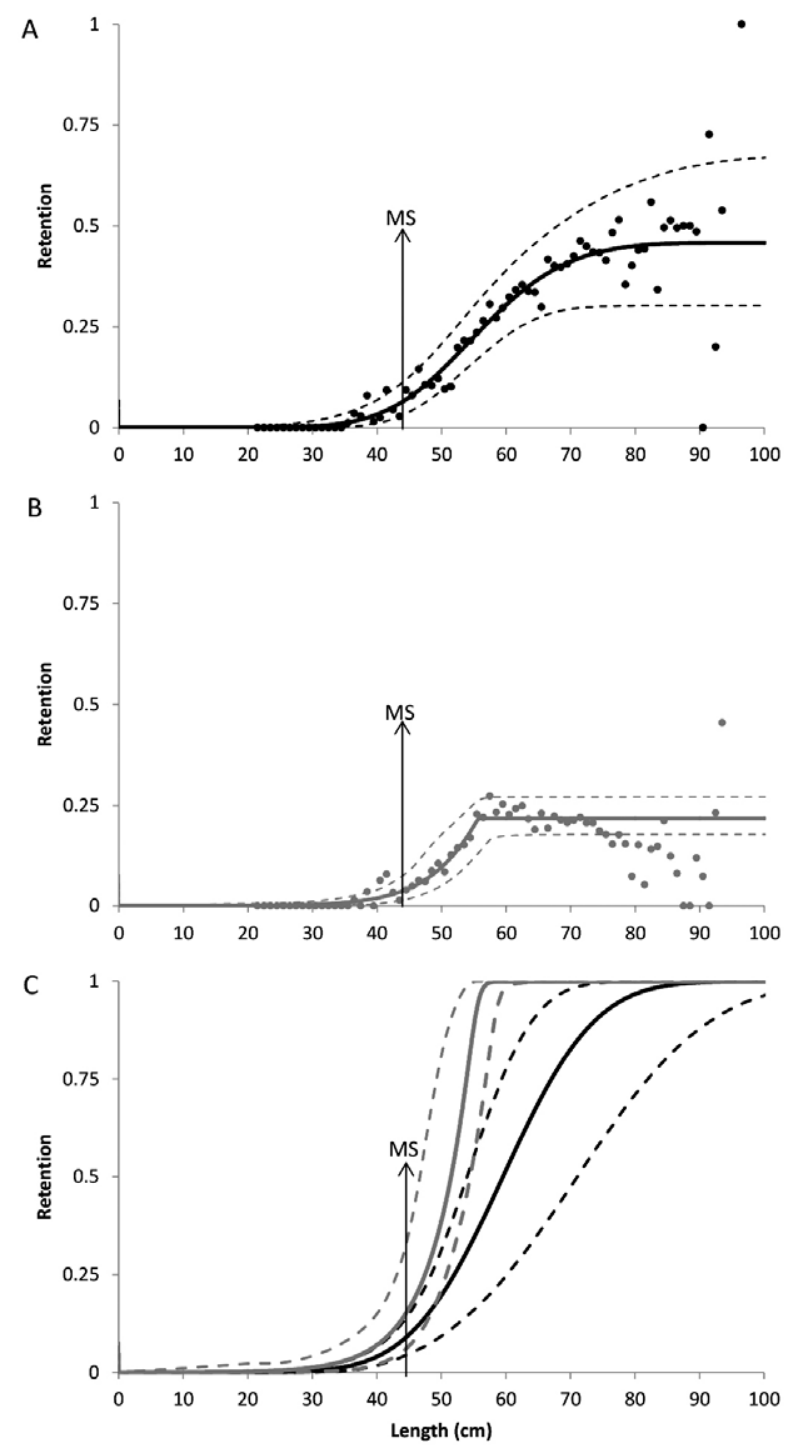

Fig. 2. - Selections curves with $95 \%$ confidence intervals (stippled lines) for the codend with the exit windows (Panels A and C; black) and the T90 codend (panels B and C; grey). The vertical arrows show the minimum target size for cod in the Barents Sea, which is $44 \mathrm{~cm}$. the mean selectivity parameters for each of the four selectivity curves were calculated for both test gears. The analysis was carried out using the analysis tool SELNET (Herrmann et al. 2012), which implements the method described in the data analysis section. All models considered resulted in deviance $>$ DOF but, since the corresponding residuals showed no defined patterns, it was considered caused by overdispersion in the data (Wileman et al. 1996). Model selection was therefore based on the QAIC. The Probit and the Richard models respectively had the lowest QAIC values for the EW codend and the T90 codend data (Table 2). Table 3 and Figure 2A-C document the fit for the selected models.

The mean L50 and SR values were 59.54 and 15.07 $\mathrm{cm}$ for the EW codend and 51.55 and $6.56 \mathrm{~cm}$ for the T90 codend (Table 3 ). There were no significant differences (at the $95 \%$ level) between the mean L50 values of the two test gears, but there was a significant difference between their mean SR values. Furthermore, as shown in Figure 2C, the EW codend was significantly more selective for fish in the length range $\sim 55-76 \mathrm{~cm}$.

\section{DISCUSSION}

In this study, we present a methodology for analysing unpaired test and control selectivity data. We have developed a double bootstrapping approach to calculate the mean selectivity parameters and their 95\% confidence ranges. This approach permits us to analyse selectivity data from fisheries, where for scientific or operational reasons it may be difficult to use the covered codend or any of the paired gear methods described in the introduction. There may also be circumstances in which, although a paired method may have been used, there is uncertainty regarding the validity of the assumption that similar populations enter the gear at the paired haul level. As long as it can be assumed that, on average, over the course of an experimental trip, similar populations enter the test and control gears, the approach described here may be preferable and provide more realistic estimates of the confidence intervals of the selectivity parameters. This is particularly the case for alternate haul methods applied to fisheries such as Danish/Scottish seining, in which there is likely to be both temporal and spatial differences between hauls/shots.

We demonstrate this approach by applying it to data from selectivity trials in the Barents Sea pelagic trawl cod fishery. We show that the mean L50 and SR values are 59.5 and $15.1 \mathrm{~cm}$ for the EW codend and 51.6 and $6.6 \mathrm{~cm}$ for the T90 codend (Table 3). We can compare these results with those of some previous studies for similar gears on demersal trawls. Grimaldo et al. (2007) tested EWs with mesh sizes of 128, 132 and 153 $\mathrm{mm}$, and obtained L50 values of 53.6, 56.4 and 57.3 $\mathrm{cm}$, respectively, while, Grimaldo et al. (2008) found that another $128 \mathrm{~mm} \mathrm{EW} \mathrm{had} \mathrm{a} \mathrm{mean} \mathrm{L50} \mathrm{of} 53.9 \mathrm{~cm}$. In terms of their selection factor (L50/mesh size), these results are respectively $0.42,0.43,0.37$ and 0.42 , which compare extremely well with the 0.42 of our trials. The corresponding SRs were respectively 9.3, 8.0, 6.8 and 
$8.5 \mathrm{~cm}$, which are lower than the results obtained in our trials. Our selectivity results are obtained based on fishing trials consisting of only 22 hauls: 5 hauls with the EW codend, 4 with the T90 codend and 13 with the control codend. This limited number of hauls affects the uncertainty of the results presented, and therefore they need to be interpreted with care. However, the method presented accounts correctly for the uncertainty in the results caused by the limited dataset. This limitation is reflected in the confidence bands of the size selection curves and parameters that are provided together with the results (Table 3, Fig. 2). Therefore, as long as these confidence bands are considered when making conclusions, the limited number of hauls in the study should not be a major concern.

Herrmann et al. (2013b) tested the performance of a $124.4 \mathrm{~mm}$ mesh size T90 codend built with $8-\mathrm{mm}$ PE twine in the Baltic and obtained a mean L50 value of $38.90 \mathrm{~cm}$, while Wienbeck et al. (2013) found that a 126$\mathrm{mm}$ T90 codend had a mean L50 of $43.4 \mathrm{~cm}$. These sets of results give a selection factor of 0.31 and 0.34 respectively, which again correspond well with the 0.37 of the trials reported here. The SRs estimated in these two studies were respectively 5.01 and $6.7 \mathrm{~cm}$, which correspond well with that obtained in our study (Table 3 ).

One of the objectives of this study was to investigate whether the grid systems being used in the Barents Sea cod fishery can be replaced by alternative selective gears. The minimum target size for cod in the Barents Sea is $44 \mathrm{~cm}$ and no more than $15 \%$ of the catch (by number) can be made up of undersized fish. Thus, an optimal selection device for this fishery should provide a sharp selection profile just above 44 $\mathrm{cm}$ so that the majority of fish above $44 \mathrm{~cm}$ would be retained and the majority below would be released from the gear. Sistiaga et al. (2010) have shown that a $55-\mathrm{mm}$ Sort-V grid combined with diamond mesh codends had L50 values in the range $51.6-55.9 \mathrm{~cm}$, which are not significantly different from the results we have here for either the EW or T90 gears (at the 95\% level). There is, however, a significant difference between the mean SR values of these two gears and, as shown in Figure 2C, the T90 codend is closer to the $44 \mathrm{~cm}$ minimum landing size and retains significantly more fish in the length range $55-76 \mathrm{~cm}$. Based on these results, this study suggests that from the fishers point of view the T90 codend is perhaps a more acceptable alternative device than that with the EW. We must be cautious, however, in drawing this conclusion, because the results are based on very few hauls and, as described above, the average catch rate observed for the test hauls carried out with the codend with the EWs was $13500 \mathrm{~kg} \mathrm{~h}^{-1}$, whereas the average catch rate observed when testing the T90 codend was $6600 \mathrm{~kg} \mathrm{~h}^{-1}$ (Table 1). These differences in the entry rate are substantial and may have contributed to the significant differences in SR estimated between the systems. In addition, the SR estimates for the EW codend are high when compared with other studies.

The analysis approach in this study provides an assessment of the average size selectivity of a group of hauls carried out with a specific test gear. This is what
Millar et al. (2004) named a fishery selectivity curve. The approach of estimating a fishery selectivity curve based on a group of hauls has been applied in several recent trawl selectivity studies (Brčić et al. 2015, Herrmann et al. 2015, Özbilgin et al. 2015, Sala et al. 2015, Sistiaga et al. 2015, Lövgren et al. 2016). However, all these studies were based on covered or paired data collection, and the bootstrapping method applied to account for the uncertainty in the results is different from the one described in this study. Furthermore, the analysis carried out in all these other studies would not allow the uncertainty due to the unpaired nature of the data collection to be incorporated in the results. As long as we consider correctly the confidence limits obtained using the unpaired analysis method, the results and the fishery selectivity curves estimated with the method presented here would not be significantly biased compared with the results that would have been obtained with a paired data collection method. This is so because both approaches estimate the selectivity curves and parameters based on pooling data over hauls. The main difference is that only the unpaired analysis method is able to account correctly for the increased uncertainty in the results caused by the unpaired nature of the data collection process. Since the analysis is made at haul group level and not at individual haul level, the analysis method described does not account for the potential effect of uncontrolled variables (e.g. codend catch size) between hauls. However, this is not a problem for the assessment of size selectivity as long as these uncontrolled parameters vary between hauls in the same way as they vary in the commercial fishery.

The unpaired analysis approach described is here applied to estimate the size selectivity in the aft part of a pelagic trawl. However, this approach can also be applied to quantify other aspects of the catch performance of a fishing gear while accounting correctly for the uncertainties resulting from using an unpaired data collection method. Specifically, Sistiaga et al. (2015 and 2016) used the unpaired analysis approach to investigate the effect of lifting the sweeps of a trawl from the seabed on the catch performance of respectively cod and haddock. Further, Notti et al. (2016) applied the unpaired analysis approach to investigate the relative catch performance of a surrounding net without the purse line in the Mediterranean Sea. However, the current study is the first in which the unpaired analysis approach has been developed and adopted to study size selectivity in the aft of a trawl gear.

\section{ACKNOWLEDGEMENTS}

We would like to thank the crew of M/Tr Ramoen for their help and support during the cruise. We would like to express our gratitude to Dr. Rob Fryer for helpful discussions in relation to the model development. Further, we want to acknowledge the two anonymous reviewers, whose comments and suggestions helped improve the final version of this paper. This study was partly financed by the Norwegian Fisheries and Aquaculture Research Fond (FHF) and the Norwegian Fisheries Directorate. 


\section{REFERENCES}

Akaike H. 1974. A new look at the statistical model identification. IEEE Trans. Auto. Control 19: 716-722. http://dx.doi.org/10.1109/TAC.1974.1100705

Brčić J., Herrmann B., Sala A. 2015. Selective characteristics of a shark-excluding grid device in a Mediterranean trawl. Fish. Res. $172,352-360$. http://dx.doi.org/10.1016/j.fishres.2015.07.035

Council Regulation (Ec) No 517/2008, of 10 June 2008 laying down detailed rules for the implementation of Council Regulation (EC) No. 850/98 as regards the determination of the mesh size and assessing the thickness of twine of fishing nets. Official Journal of the European Union L 151.

Eigaard O., Herrmann B. Nielsen J.R. 2012. Influence of grid orientation and time of day on grid sorting in a small-meshed trawl fishery for Norway pout (Trisopterus esmarkii). Aquat. Living Resour. 25: 15-26. http://dx.doi.org/10.1051/alr/2011152

Fryer R.J. 1991. A model of between-haul variation in selectivity. ICES J. Mar. Sci. 48: 281-290. http://dx.doi.org/10.1093/icesjms/48.3.281

Grimaldo E., Larsen R.B., Holst R. 2007. Exit Windows as an alternative selective system for the Barents Sea Demersal Fishery for cod and haddock. Fish. Res. 85: 295-305. http://dx.doi.org/10.1016/j.fishres.2007.03.005

Grimaldo E., Sistiaga M., Larsen R.B. 2008. Evaluation of codends with sorting grids, exit windows and diamond meshes: Size selectivity and fish behaviour. Fish. Res. 91: 271-280. http://dx.doi.org/10.1016/j.fishres.2007.12.003

Herrmann B., Priour D., Krag L.A. 2006. Theoretical study of the effect of round straps on the selectivity in a diamond mesh codend. Fish. Res. 80: 148-157. http://dx.doi.org/10.1016/j.fishres.2006.04.018

Herrmann B., Sistiaga M., Nielsen K.N., et al. 2012. Understanding the size selectivity of red fish (Sebastes spp.) in North Atlantic trawl codends. J. Northw. Atl. Fish. Sci. 44: 1-13. http://dx.doi.org/10.2960/J.v44.m680

Herrmann B., Sistiaga M., Larsen R.B., et al. 2013a. Size selectivity of redfish (Sebastes spp.) in the Northeast Atlantic using gridbased selection systems for trawls. Aquat. Living Resour. 26: 109-120. http://dx.doi.org/10.1051/alr/2013051

Herrmann B., Wienbeck H., Moderhak V., et al. 2013b. The influence of twine thickness, twine number and netting orientation on codend selectivity. Fish. Res. 145: 22-36. http://dx.doi.org/10.1016/j.fishres.2013.03.002

Herrmann B., Larsen R.B., Sistiaga M., et al. 2015. Predicting Size Selection of Cod (Gadus morhua) in Square Mesh Codends for Demersal Seining: a Simulation-based Approach. Fish. Res. http://dx.doi.org/10.1016/j.fishres.2015.07.015

Lövgren J., Herrmann B., Feekings J. 2016. Bell-shaped size selection in a bottom trawl: A case study for Nephrops directed fishery with reduced catches of cod. Fish. Res. http://dx.doi.org/10.1016/j.fishres.2016.03.019

Millar R.B. 1992. Estimating the size-selectivity of fishing gear by conditioning on the total catch. J. Amer. Stat. Assoc. 87: 962-968

http://dx.doi.org/10.1080/01621459.1992.10476250

Millar R.B. 1993. Incorporation of between-haul variation using bootstrapping and nonparametric estimation of selection curves. Fish. Bull. 91: 564-572.

Millar R.B., Fryer R.J. 1999. Estimating size-selection curves of trawls, traps, gillnets and hooks. Rev. Fish Biol. Fish. 9: 89-116. http://dx.doi.org/10.1023/A:1008838220001

Millar R.B., Broadhurst M.K., Macbeth W.G. 2004. Modelling between-haul variability in the size selectivity of trawls. Fish. Res. 67: 171-181. http://dx.doi.org/10.1016/j.fishres.2003.09.040

Norwegian Fisheries Directorate (J-7-2016). 2016. Regulations for fishing practices at sea J-7-2016, Norwegian Fisheries Directorate (www.fiskeridir.no), Bergen, Norway. 57 pp. (In Norwegian).

Notti E., Brčić J., De Carlo F., et al. 2016. Assessment of the relative catch performance of a surrounding net without the purse line as an alternative to a traditional boat seine in small-scale fisheries. Mar. Coast. Fish. 8: 81-91. http://dx.doi.org/10.1080/19425120.2015.1095827

Özbilgin H., Eryaşar A.R., Gökçe G., et al. 2015. Size selectivity of hand and machine woven codends and short term commercial loss in the northeastern Mediterranean. Fish. Res. 164: 73-85 http://dx.doi.org/10.1016/j.fishres.2014.10.022

Richard S.A. 2008. Dealing with overdispersed count data in applied ecology. J. Appl. Ecol. 45: 218-227. http://dx.doi.org/10.1111/j.1365-2664.2007.01377.x

Sala A., Lucchetti A., Perdichizzi A., et al. 2015. Is square-mesh better selective than larger mesh? A perspective on fisheries management for Mediterranean trawl fisheries. Fish. Res. 161: 182-190. http://dx.doi.org/10.1016/j.fishres.2014.07.011

Sistiaga M., Herrmann B., Grimaldo E., et al. 2010. Assessment of dual selection in grid based selectivity systems. Fish. Res. 105: 187-199. http://dx.doi.org/10.1016/j.fishres.2010.05.006

Sistiaga M., Herrmann B., Grimaldo E., et al. 2015. Effect of lifting the sweeps on bottom trawling catch efficiency: A case study of the Northeast arctic cod (Gadus morhua) trawl fishery. Fish. Res. 167: 164-173. http://dx.doi.org/10.1016/j.fishres.2015.01.015

Sistiaga M., Herrmann B., Grimaldo E., et al. 2016. The effect of sweep bottom contact on the catch efficiency of haddock. Fish. Res. 179: 302-307. http://dx.doi.org/10.1016/j.fishres.2016.03.016

Wienbeck H., Herrmann B., Jordan P.F., et al. 2013. A comparative analysis of legislated and modified Baltic Sea trawl codends for simultaneously improving the size selection of cod (Gadus morhua) and plaice (Pleuronectes platessa). Fish. Res. 150: 28-37. http://dx.doi.org/10.1016/j.fishres.2013.10.007

Wileman D., Ferro R.S.T., Fonteyne R., et al. (eds). 1996. Manual of methods of measuring the selectivity of towed fishing gears. ICES Coop. Res. Rep. No. 215. 